\title{
Morphology, Anatomy and Secondary Metabolites Investigations of Premna odorata Blanco and Evaluation of Its Anti-Tuberculosis Activity Using In Vitro and In Silico Studies
}

\author{
Fadia S. Youssef ${ }^{1, *(D)}$, Elisa Ovidi ${ }^{2}\left(\mathbb{D}\right.$, Nawal M. Al Musayeib ${ }^{3}$ and Mohamed L. Ashour $1, *$ (D) \\ 1 Department of Pharmacognosy, Faculty of Pharmacy, Ain-Shams University, Abbasia, Cairo 11566, Egypt \\ 2 Department for the Innovation in Biological, Agrofood and Forestal Systems, Tuscia University, 01100 Viterbo, \\ Italy; eovidi@unitus.it \\ 3 Department of Pharmacognosy, College of Pharmacy, King Saud University, Riyadh 11495, Saudi Arabia; \\ nalmusayeib@ksu.edu.sa \\ * Correspondence: fadiayoussef@pharma.asu.edu.eg (F.S.Y.); ashour@pharma.asu.edu.eg (M.L.A.)
}

Citation: Youssef, F.S.; Ovidi, E.; Musayeib, N.M.A.; Ashour, M.L. Morphology, Anatomy and Secondary Metabolites Investigations of Premna odorata Blanco and Evaluation of Its Anti-Tuberculosis Activity Using In Vitro and In Silico Studies. Plants 2021, 10, 1953. https://doi.org/10.3390/plants 10091953

Academic Editors: Fico Gelsomina and Claudia Giuliani

Received: 21 August 2021

Accepted: 14 September 2021

Published: 18 September 2021

Publisher's Note: MDPI stays neutral with regard to jurisdictional claims in published maps and institutional affiliations.

Copyright: (c) 2021 by the authors. Licensee MDPI, Basel, Switzerland. This article is an open access article distributed under the terms and conditions of the Creative Commons Attribution (CC BY) license (https:/ / creativecommons.org/licenses/by/ $4.0 /)$.

\begin{abstract}
In-depth botanical characterization was performed on Premna odorata Blanco (Lamiaceae) different organs for the first time. The leaves are opposite, hairy and green in color. Flowers possess fragrant aromatic odors and exist in inflorescences of 4-15 cm long corymbose cyme-type. In-depth morphological and anatomical characterization revealed the great resemblance to plants of the genus Premna and of the family Lamiaceae, such as the presence of glandular peltate trichomes and diacytic stomata. Additionally, most examined organs are characterized by non-glandular multicellular covering trichomes, acicular, and rhombic calcium oxalate crystals. P. odorata leaves $n$-hexane fraction revealed substantial anti-tuberculous potential versus Mycobacterium tuberculosis, showing a minimum inhibition concentration (MIC) of $100 \mu \mathrm{g} / \mathrm{mL}$. Metabolic profiling of the $n$-hexane fraction using gas-chromatography coupled to mass spectrometry (GC/MS) analysis revealed 10 major compounds accounting for $93.01 \%$, with trans-phytol constituting the major compound $(24.06 \%)$. The virtual screening revealed that trans-phytol highly inhibited MTB C171Q receptor as $M$. tuberculosis KasA ( $\beta$-ketoacyl synthases) with a high fitting score $(\Delta \mathrm{G}=-15.57 \mathrm{kcal} / \mathrm{mol})$ approaching that of isoniazid and exceeding that of thiolactomycin, the co-crystallized ligand. Absorption, distribution, metabolism, excretion and toxicity predictions (ADME/TOPKAT) revealed that trans-phytol shows lower solubility and absorption levels when compared to thiolactomycin and isoniazid. Still, it is safer, causing no mutagenic or carcinogenic effects with higher lethal dose, which causes the death of $50 \%$ (LD50). Thus, it can be concluded that $P$. odorata can act as a source of lead entities to treat tuberculosis.
\end{abstract}

Keywords: anatomy; anti-tuberculous activity; Lamiaceae morphology; molecular docking; Premna odorata; secondary metabolites

\section{Introduction}

Premna L. is a plant genus that was previously classified as a member of Verbenaceae [1], and recently, it has been moved to the family Lamiaceae and belongs to the subfamily Viticodeae [2]. Premna comprises about 200 species natively growing in Australia, Africa, subtropical and tropical Asia, and the Pacific Islands [2]. The term Premna is taken from the Greek word "premon", which means tree stump, reflecting the twisted and short trunks of $P$. serratifolia L., the first discovered species of this genus. Members of this genus are characterized morphologically by being shrubs or trees, rarely pyroherbs as $P$. herbacea Roxb or lianas as P. trichostoma Miq. [3].

Certain Premna species are popular by having young twigs accompanied by small scales of triangular shapes and decussate arrangement present at the base and promptly fall when the branch becomes older. Most Premna species carry hairy leaves arranged 
in a decussate manner with the presence of a ridge among the petioles. Regarding the shape of the calyx, two types are present; one possesses four isomorphic lobes that are kept unchanged during the development of the flower and the formation of the fruits; meanwhile, the other is heteromorphic and possesses from zero to five lobes. In addition, the genus is characterized by two types of fruits, one is globose drupe-like fruit with fleshy mericarps, and in each mericarp there is one seed; however, the other is nearly clavoid with drupe-like single-seeded fruit with a fleshy mericarp [4].

Genus Premna is popular by the predominance of secondary metabolites belonging to various classes, including iridoid glycosides, diterpenoids, and phenylethanoids, lignans, sesquiterpenes, ceramides, megastigmanes and glyceroglycolipids. The richness in phytoconstituents is reflected in the biological activities of Premna species that show a wide array of biological effectiveness, represented mainly by their immunomodulatory, antimicrobial, anti-hyperglycemia, anti-inflammatory, cytotoxic activities [3,5].

$P$. odorata Blanco is represented mainly by small trees rarely reaching $10 \mathrm{~m}$ and was used in traditional medicine for vaginal irrigation and tuberculosis treatment. Flavonoids, iridoid glycosides and essential oils were isolated from $P$. odorata leaves and showed anti-aging and anti-tuberculosis activity $[5,6]$.

Herein, the morphological and anatomical characters of fresh plant leaves, petiole, old and young stems, their histological sections, and air-dried finely powdered samples were comprehensively studied for the first time. Metabolic profiling of secondary metabolites in the $n$-hexane fraction obtained from the leaves was performed using GC/MS analysis. Furthermore, evaluation of the anti-tuberculous activity of $n$-hexane fraction using in vitro and in silico assays. In silico studies were performed on major metabolites identified from the $n$-hexane fraction on MTB C171Q receptor as KasA ( $\beta$-ketoacyl synthases) to provide a solid support to consolidate what was previously reported in the literature about its anti-tuberculosis activity, which was also highlighted for the first time. Besides, ADME/TOPKAT predictions, major metabolites were identified from the $n$-hexane fraction were performed to highlight their pharmacodynamic, pharmacokinetic behavior and toxic potential.

\section{Results and Discussion}

\subsection{Botanical Investigations}

\subsubsection{Macromorphological Characterization}

P. odorata Blanco (Lamiaceae) is an evergreen small tree or shrub nearly $10 \mathrm{~m}$ tall with diameter breast height $(\mathrm{DBH})$ ranging between $15-30 \mathrm{~cm}$. The leaves are opposite, hairy and green in color. Flowers exist in inflorescences of $4-15 \mathrm{~cm}$ long that are of corymbose cyme type. The flowers are pale green, yellowish or white with a fragrant aromatic odor. It flowers all year; meanwhile, fruit production occurs between March and November. It displays monopodial branching (Figure 1A).

\section{Leaf}

The leaves are oppositely arranged as simple, exstipulate, cauline, pubescent and petiolate. It is green in color, either old or young. It has variable shapes, either ovate, obovate, rotundate, to lanceolate, of 7-20 cm in length and $4-13.5 \mathrm{~cm}$ in width, with petioles of $20-80 \mathrm{~mm}$ long, velutinous to sparsely hairy. The leaf is characterized by an acuminate apex, emarginate to cordate base, serrate to entire margins. Both surfaces of the leaf are covered with hairs; meanwhile, venation of the leaf is tri-veined, arising from the base, with 3-7 main side veins. Its texture is subchartaceous or membranous and pubescent with a characteristic fragrant odor (Figure 1B-D).

Stem

Young stems are cylindrical, hairy and light brown, showing monopodial branching and opposite phyllotaxis; the old stems are erect, woody, and cylindrical with hairy texture and darker in color. Both young and old stems are brittle, break with a short fracture, and 
show a white solid interior and have nodes and internodes that are 7-9 $\mathrm{cm}$ in length. They have a fragrant odor and a characteristic taste (Figure 1C).
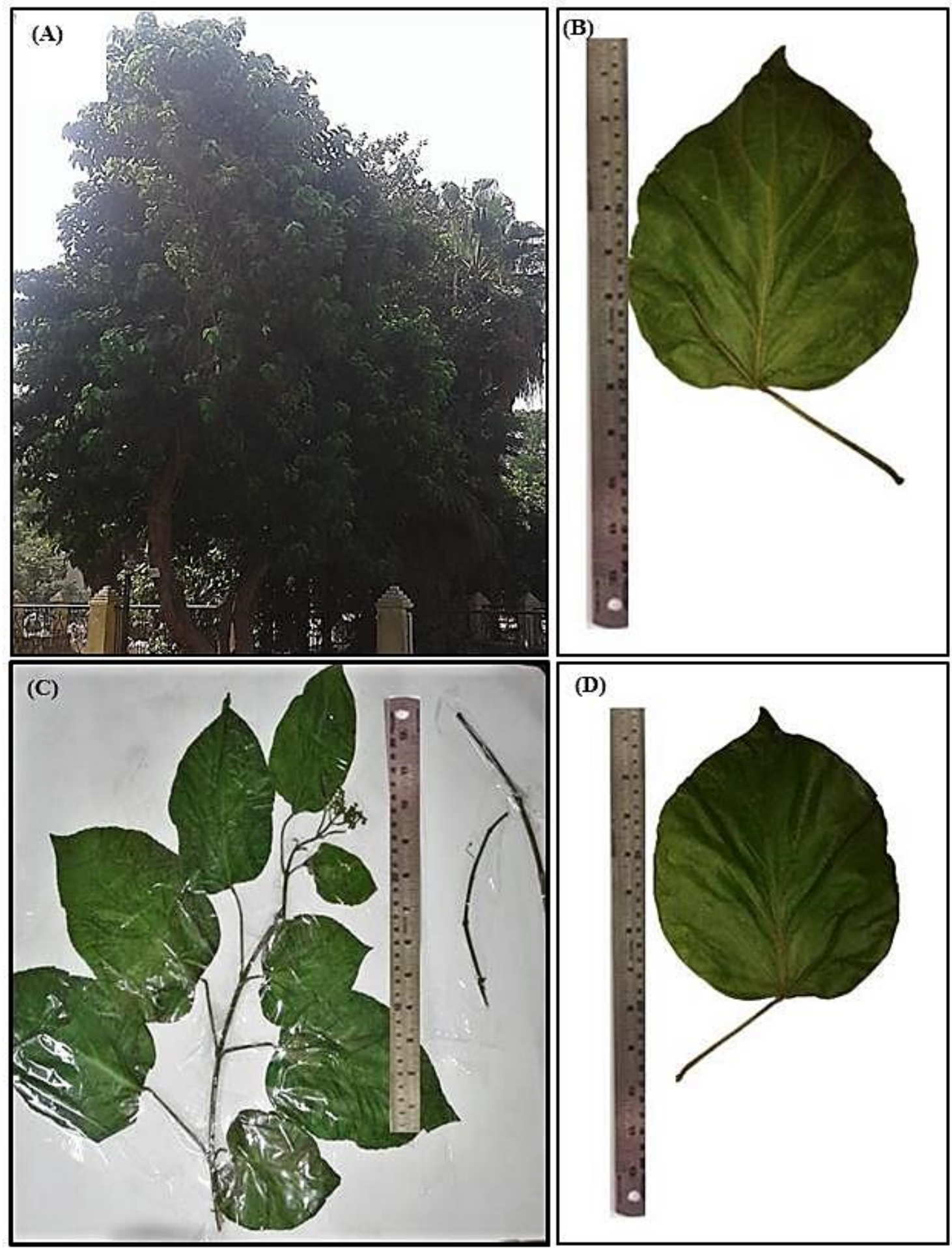

Figure 1. Morphological characterization of $P$. odorata displaying $(\mathbf{A})$ entire tree, $(\mathbf{B})$ leaf lower surface $(\times 0.25),(\mathbf{C})$ leafy branch $(\times 0.17)$ and $(D)$ leaf upper surface $(\times 0.25)$. 


\subsubsection{Micromorphological Characterization}

Leaf

Lamina

The transverse cross-section in P. odorata leaf displayed the existence of upper and lower epidermis thickened with cuticle. The upper epidermis showed big, rectangular or cuboid-shaped cells; meanwhile, the lower epidermis displayed smaller cuboid-shaped cells than those of the upper epidermis. Stomata of the diacytic type are more prevalent in the lower epidermis. The lamina is characterized by the presence of dorsiventral mesophyll that is heterogeneous and discriminated into palisade and spongy layers. Below the upper epidermis, 1-2 layers of palisade cells that are highly compact cylindrical parenchymal cells and continuous in the midrib region in the form of a single layer of small cells. Palisade cells are characterized by the presence of narrow intercellular spaces and show green plastids. The spongy tissue comprises 4-5 layers of spherical parenchyma cells displaying intercellular spaces and interrupted by vascular bundles in small lateral branches. Two types of trichomes are present, with more prevalence on the lower epidermis, and appear more clearly in the powdered form. The first is non-glandular multicellular covering trichome with a 2-celled base. Meanwhile, the second is glandular peltate trichome (Figure 2A,B,D).

\section{Midrib}

It is convex in the upper surface of the leaf (adaxial side), possessing epidermis in a single layer, with cells cuboid in shape, thickened with cuticle. The upper epidermis is followed by 5-6 layers of collenchyma cells, and the cortical tissue is formed of several rows of collenchyma cells facing the lower epidermis with acicular and rhombic crystals of calcium oxalate. A large bowel-shaped collateral vascular bundle exists in the center of the midrib, crossed by medullary rays formed of elongated lines in the form of uni- to biseriate lines. The vascular bundles are formed of phloem and xylem. The former is composed of thin-walled cells of parenchyma; meanwhile, the latter is composed of xylem vessels, fibers with wide lumina, blunt apices, and wood parenchyma. The xylem is completely lignified and revealed a red color upon treatment with concentrated hydrochloric acid and phloroglucinol. The xylem vessels are thickened spirally, whereas wood parenchyma is composed of elongated cells with lignified pitted walls. The phloem area is surrounded by sclerenchyma patches, while the ground tissue is made of parenchyma occupying its center with abundant acicular and rhombic crystals of calcium oxalate. Arrangement of the xylem vessels radially occurs with the metaxylem directed toward the periphery (abaxial surface), while the protoxylem is directed toward the center (adaxial surface). Abundant crystals of calcium oxalate are also present. Numerous non-glandular multicellular covering trichomes and glandular peltate trichomes exist on the upper and lower epidermis (Figure 2A,C,D).

\section{Petiole}

A transverse section obtained from the petiole revealed a cubical outline formed by a single layer of cubical thickened cells with diacytic stomata accompanied by both non-glandular and glandular peltate trichomes. Below the epidermis, the cortex comprises 6-7 layers of small-sized thick-walled angular collenchymatous cells followed by 4-5 layers of large-sized polygonal collenchyma cells containing abundant rhombic calcium oxalate crystals and showing sinuous cell walls. The petiole has collateral vascular bundles extending radially, taking a circular shape on the ventral side and a bowl shape on the dorsal side. They consist of an outer phloem and inner xylem, with the metaxylem directed toward the periphery (abaxial surface), with the protoxylem directed toward the center (adaxial surface). Vascular bundles are separated by medullary rays formed of elongated lines in the form of uni- to biseriate lines. As in the leaves, phloem is composed of thinwalled parenchyma cells; meanwhile, the xylem is composed of xylem vessels, fibers with wide lumina and blunt apices and wood parenchyma. The xylem is completely lignified and revealed a red color upon treatment with concentrated hydrochloric acid and phloroglucinol. The xylem vessels are thickened spirally, whereas wood parenchyma is composed of elongated cells with lignified pitted walls. The ground tissue existing in 
the central region of the petiole is composed of big parenchyma cells with few scattered rhombic calcium oxalate crystals (Figure $3 \mathrm{~A}-\mathrm{C}$ ).
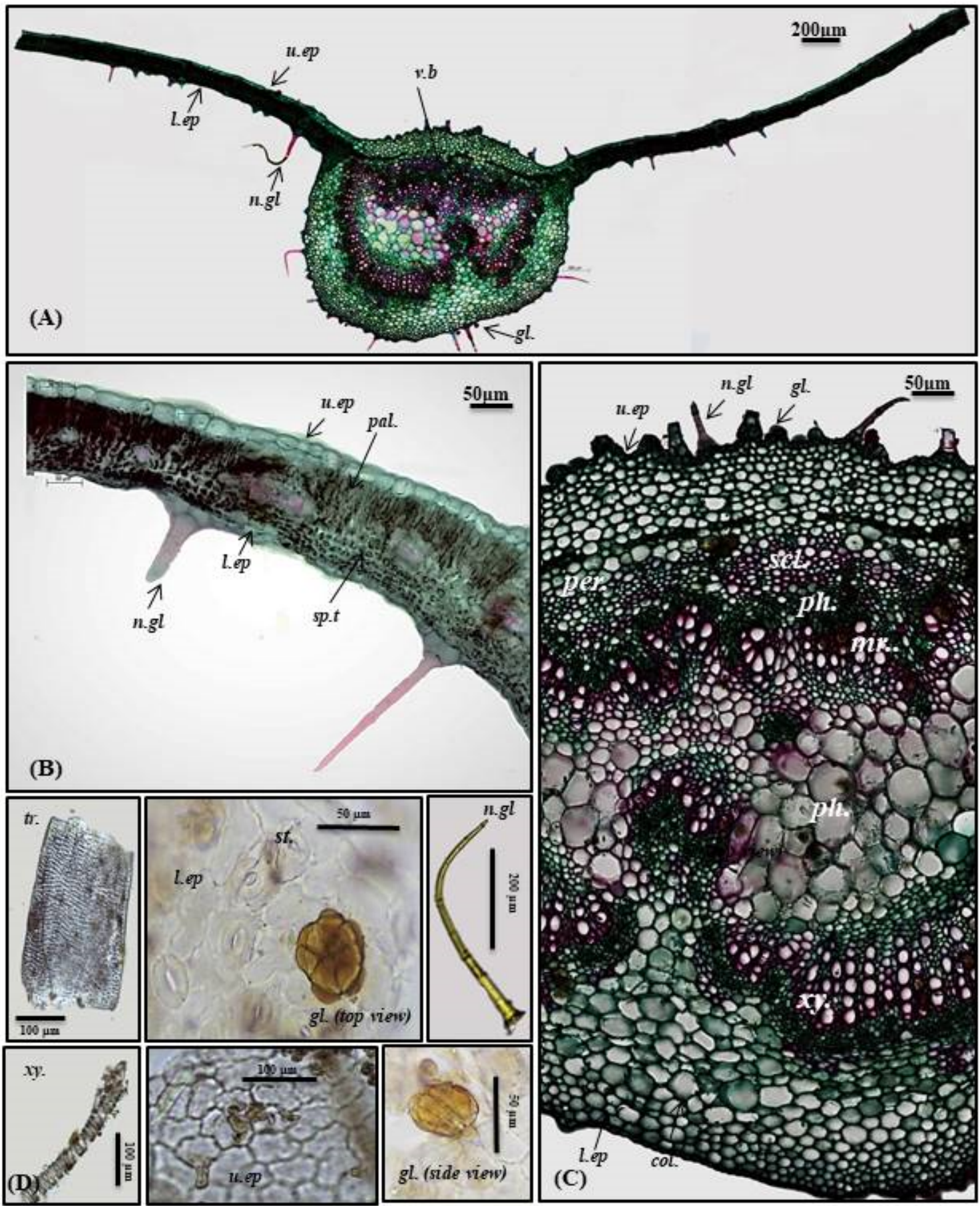

Figure 2. Micromorphology of P. odorata leaf showing (A) entire T.S $(\times 100),($ B $)$ lamina $(\times 400),(C)$ midrib region $(\times 400)$, and (D) isolated elements. Col., collenchyma; gl., glandular peltate trichome; l.ep., lower epidermis; $M r$., medullary rays; n.gl., non-glandular trichome; pal., palisade; per., pericycle; $p h .$, phloem; scl., sclerenchyma; sp.t., spongy tissue; tr., tracheids; u.ep, upper epidermis; v.b., vascular bundle; $x y$., xylem. 

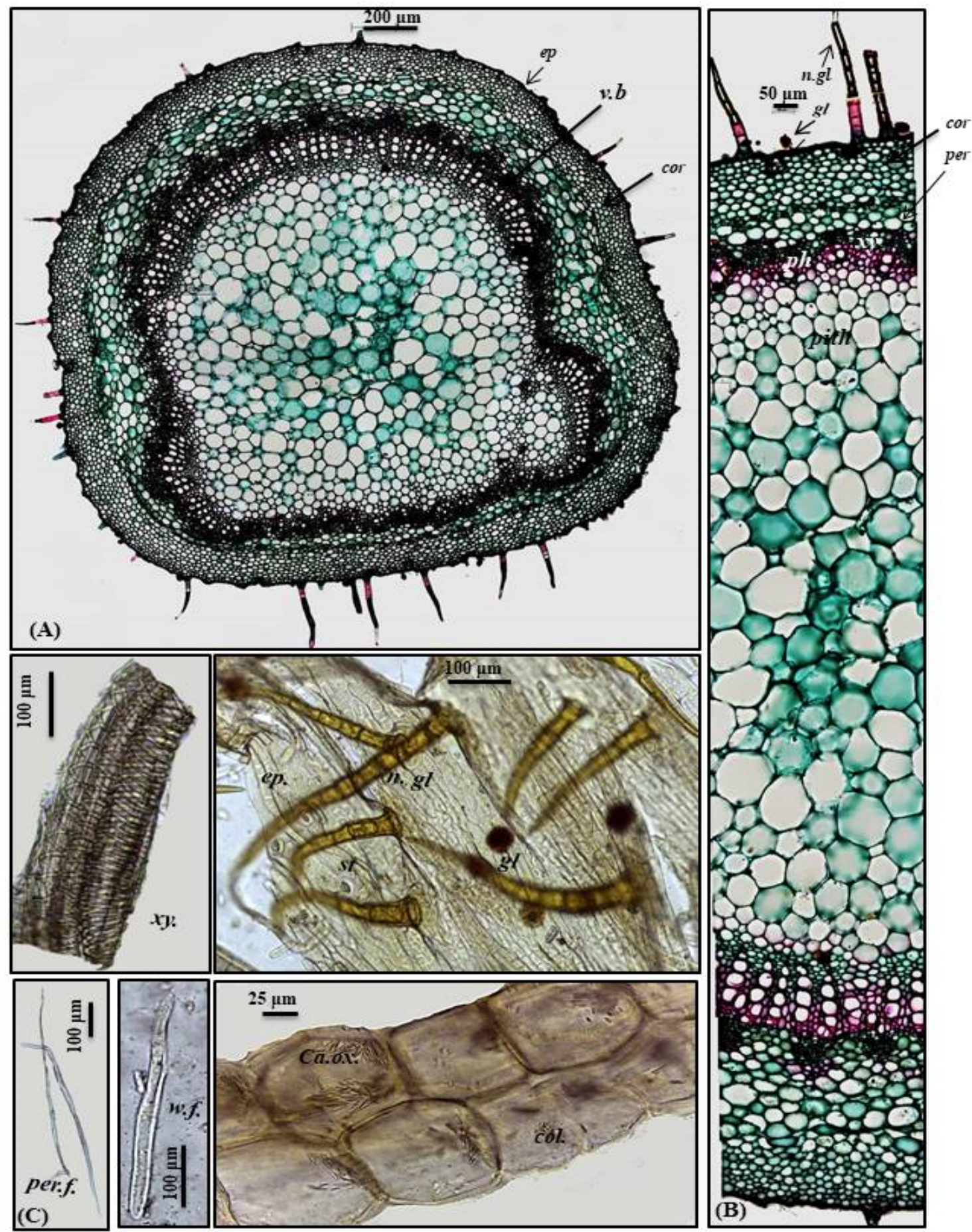

Figure 3. Micromorphology of P. odorata petiole showing $(\mathbf{A})$ entire T.S $(\times 100),(\mathbf{B})$ a part of T.S $(\times 400)$ and $(\mathbf{C})$ isolated elements. Ca.ox., acicular crystals of calcium oxalate; cor., cortex; col., collenchyma; ep., epidermis; gl., glandular peltate trichome; $n . g l .$, non-glandular trichome; per., pericycle; per.f., pericycle fiber; ph., phloem; v.b, vascular bundle; $w . f .$, wood fiber; $x y .$, xylem.

Stem

Young stem

A transverse section obtained from the young stem revealed a quasi-square outline with a slight curvature in the middle of only two opposite sides composed of epidermis, narrow cortex and vascular bundles. It is covered by both non-glandular and glandular 
peltate trichomes. The epidermal cells are present in only a single layer, and they are nearly square in appearance that is densely arranged and thickened with cuticle having diacytic stomata. The cortex is narrowly composed of 5-6 rows of nearly circular thickened collenchyma cells ending in a pericycle surrounding the vascular bundles. The pericycle is continuously formed of 1-2 rows of polygonal small, highly thickened, densely arranged cells. The vascular region is continuously composed of open collateral vascular bundles with phloem, cambium, and xylem traversed by medullary rays. Additionally, the phloem area is surrounded by sclerenchyma patches, and the xylem is lignified formed of spirally thickened xylem vessels. The pith represents a big part of the total stem diameter consisting of large, polygonal, thin-walled cells containing acicular crystals of calcium oxalate (Figure 4A,B).
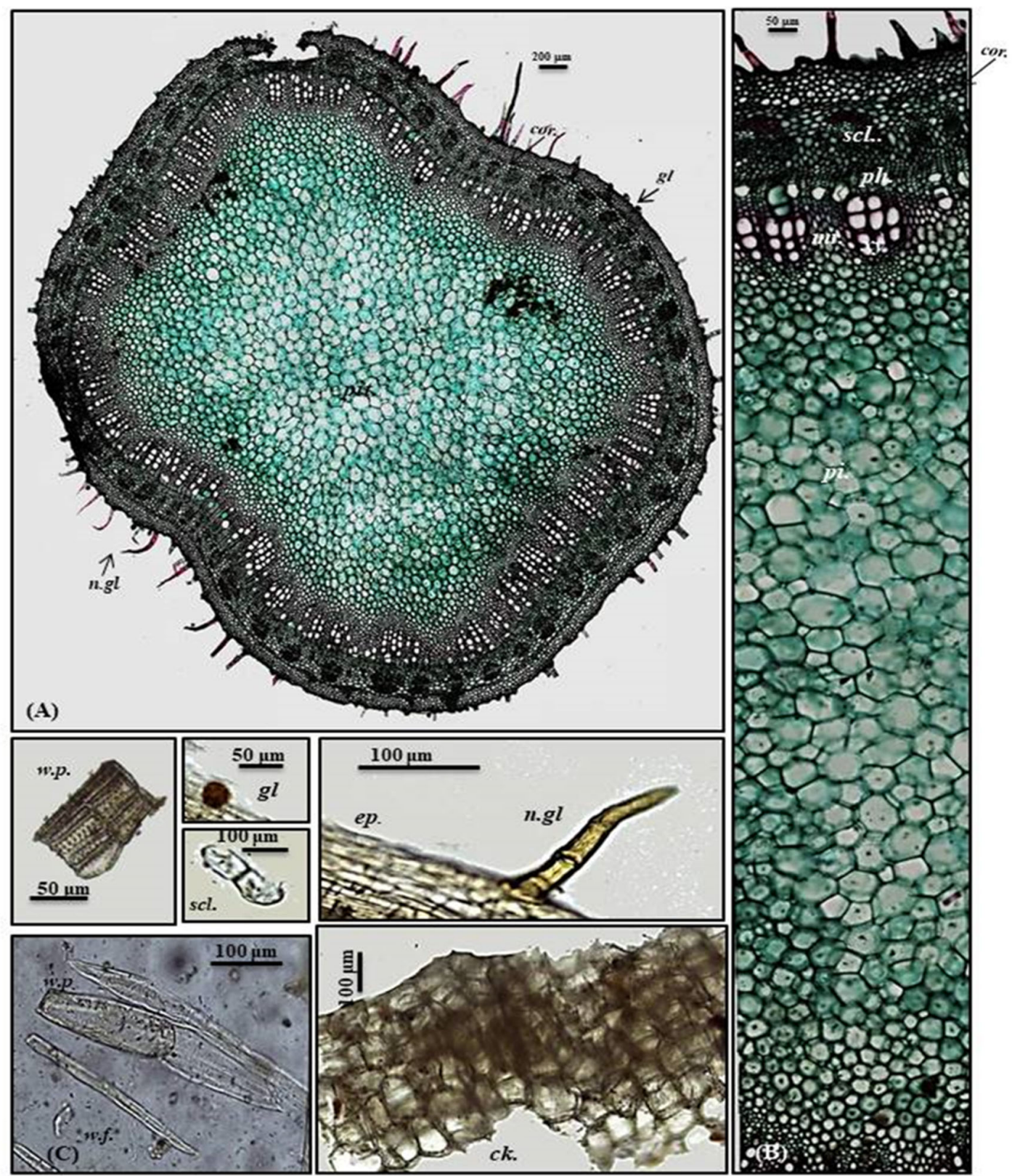

Figure 4. Micromorphology of P. odorata young stem branch showing (A) entire T.S $(\times 100),($ B $)$ a part of T.S $(\times 400)$ and (C) isolated elements. Ck., cork (old stem branch); cor., cortex; $e p$., epidermis; gl., glandular peltate trichome; $n . g l .$, nonglandular trichome; per., pericycle; per.f., pericycle fiber; $p i$. , pith; ph., phloem; scl., sclerenchyma; tr., tracheid; $w . f$. , wood fiber; w.p., wood parenchyma.; $x y .$, xylem. 


\section{Old stem}

A transverse section obtained from the old stem revealed a nearly circular outline covered with non-glandular and glandular peltate trichomes. It is composed of cork cells followed by cork cambium and a narrow secondary cortex composed of patches of sclerenchyma, particularly above the phloem in a well-developed vascular system. The cork is formed of elongated brown cells, lignified and thickened cells, which is absent in the young stem. The vascular region is continuously composed of open collateral vascular bundles with phloem, cambium, and xylem traversed by medullary rays. The xylem occupies a wider area than in the young stem, followed by pith that is relatively narrower with respect to the young stem. It comprises nearly circular thin-walled large parenchymatous cells (Figure 5A-C). The microscopical measurements of the various elements existing in the leaves, petiole and stems of $P$. odorata are illustrated in Table 1. In-depth, comprehensive botanical study of $P$. odorata leaf, petiole and stems revealed its great resemblance to other members in genus P. odorata and Lamiaceae Family, such as the presence of glandular trichomes and diacytic stomata. The presence of diacytic stomata, covering trichomes that are unicellular or uniseriate, simple or branched as well as the glandular trichomes such as peltate or capitate hairs with unicellular stalk and unicellular or multicellular head usually formed of 8 cells radiating from the stalk that are abundant on all vegetative parts, are among the common anatomical features of all Lamiaceae species such as Mentha piperita L., Lavandula officinalis L., Ocimum basilicum L. and Thymus vulgaris L. as well $[7,8]$. Although few studies have been conducted to explore the anatomy of many Premna species, investigations performed on P. serratifolia showed great similarity with $P$. odorata in virtue of possessing sclerenchyma cells in the form of patches above the phloem, the vascular bundle in the region of the midrib takes the shape of the bowel and the stomata is diacytic in addition to glandular peltate trichomes [9].
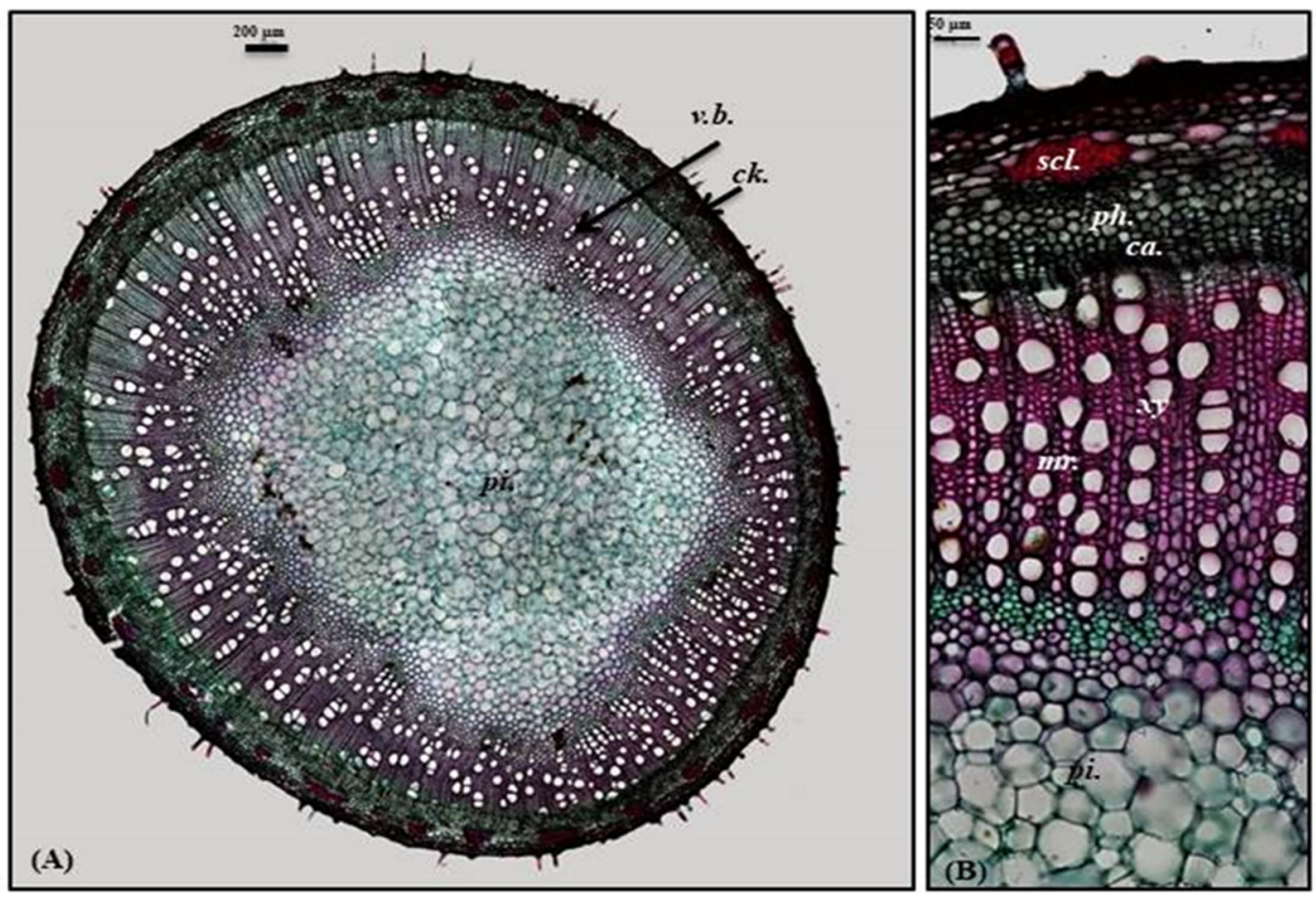

Figure 5. Micromorphology of P. odorata old stem branch showing (A) entire T.S $(\times 100)$ and $($ B) a part of T.S $(\times 400)$ Ca., cambium; Ck., cork; scl., sclerenchyma; pi., pith; ph., phloem; $x y .$, xylem. 
Table 1. The microscopical measurements of the various elements existing in the leaves, petiole and stems of $P$. odorata (in $\mu \mathrm{m}$ ).

\begin{tabular}{|c|c|c|c|c|}
\hline Item & Length & Width & Height & Diameter \\
\hline \multicolumn{5}{|l|}{ Leaf } \\
\hline Upper epidermis & $71.50-\underline{66.8}-62.20$ & $8.80-\underline{10.20}-11.00$ & $6.40-10.70-15.00$ & \\
\hline Lower epidermis & $30.45-40.18-49.90$ & $45.60-\overline{-10.10}-14.60$ & $5.20-5.50-6.80$ & \\
\hline Palisade cells & $20.30-25.47-30.64$ & $5.60-6.80-7.20$ & $15.40-\overline{16.67}-17.80$ & \\
\hline Stomata & $21.45-\overline{25.50}-29.55$ & $13.90-\overline{16.50}-19.10$ & & \\
\hline Non-glandular trichome & $250.56-\overline{400.34}-550.23$ & $47.60-\overline{50.79}-53.98$ & & \\
\hline Glandular (Peltate trichome) & $39.60-42.86-46.12$ & $30.59-35.70-40.81$ & & \\
\hline Xylem vessels & & & & $19.89-22.11-24.33$ \\
\hline \multicolumn{5}{|l|}{ Petiole } \\
\hline Epidermis & $25.00-\underline{37.50}-50.02$ & $6.50-\underline{10.40-14.32}$ & $4.90-5.50-6.10$ & \\
\hline Stomata & $20.45-\underline{25.50}-30.55$ & $14.90-16.50-18.10$ & & \\
\hline Non-glandular trichome & $300.45-\overline{375.52}-450.60$ & $46.60-\overline{51.79}-56.99$ & & \\
\hline Glandular (Peltate trichome) & $48.60-\overline{50.86}-53.12$ & $23.59-\overline{25.70}-27.81$ & & \\
\hline Xylem vessels & & & & $28.89-\underline{34.61-40.33}$ \\
\hline Wood fibers & $350.50-375.60-400.70$ & $22.59-25.30-28.00$ & & \\
\hline Pericyclic fibers & 640.44-684.70-708.95 & $7.73-10.42-13.11$ & & \\
\hline \multicolumn{5}{|l|}{ Young and old stem branch } \\
\hline Epidermis & $25.76-\underline{30.58}-35.4$ & $8.14-\underline{10.70}-13.26$ & $4.00-\underline{4.50}-5.00$ & \\
\hline Cork cells & $48.68-4 \overline{49.61-50.54}$ & $48.68-\overline{49.61}-50.54$ & & \\
\hline Non-glandular trichome & $157.50-167.52-177.54$ & $18.40-\overline{21.69}-24.98$ & & \\
\hline Glandular (Peltate trichome) & $47.60-\overline{49.86}-52.12$ & $22.39-\overline{25.30}-28.21$ & & \\
\hline Xylem vessels & & & & $27.89-\underline{35.61-41.33}$ \\
\hline Wood fibers & $320.50-375.40-430.30$ & $23.59-26.30-29.00$ & & \\
\hline Wood parenchyma & $200.00-210.00-220.00$ & $22.00-25.50-29.00$ & & \\
\hline
\end{tabular}

\subsection{Metabolic Profiling of the Leaves n-Hexane Fraction Using GC/MS Analysis}

Metabolic profiling of the $n$-hexane fraction obtained from the leaves of $P$. odorata leaves using GC/MS analysis revealed the presence of 10 major compounds accounting for $93.01 \%$. They belong mainly to oxygenated sesquiterpenes, higher alkanes and steroidal compounds. trans-Phytol constitutes the major compound (24.06\%), followed by $n$-octacosane $(15.28 \%)$ and $\alpha$-amyrin $(13.37 \%)$. Compounds identified from the $n$-hexane fraction of $P$. odorata leaves using GC/MS analysis are illustrated in Figure 6 and Table 2.

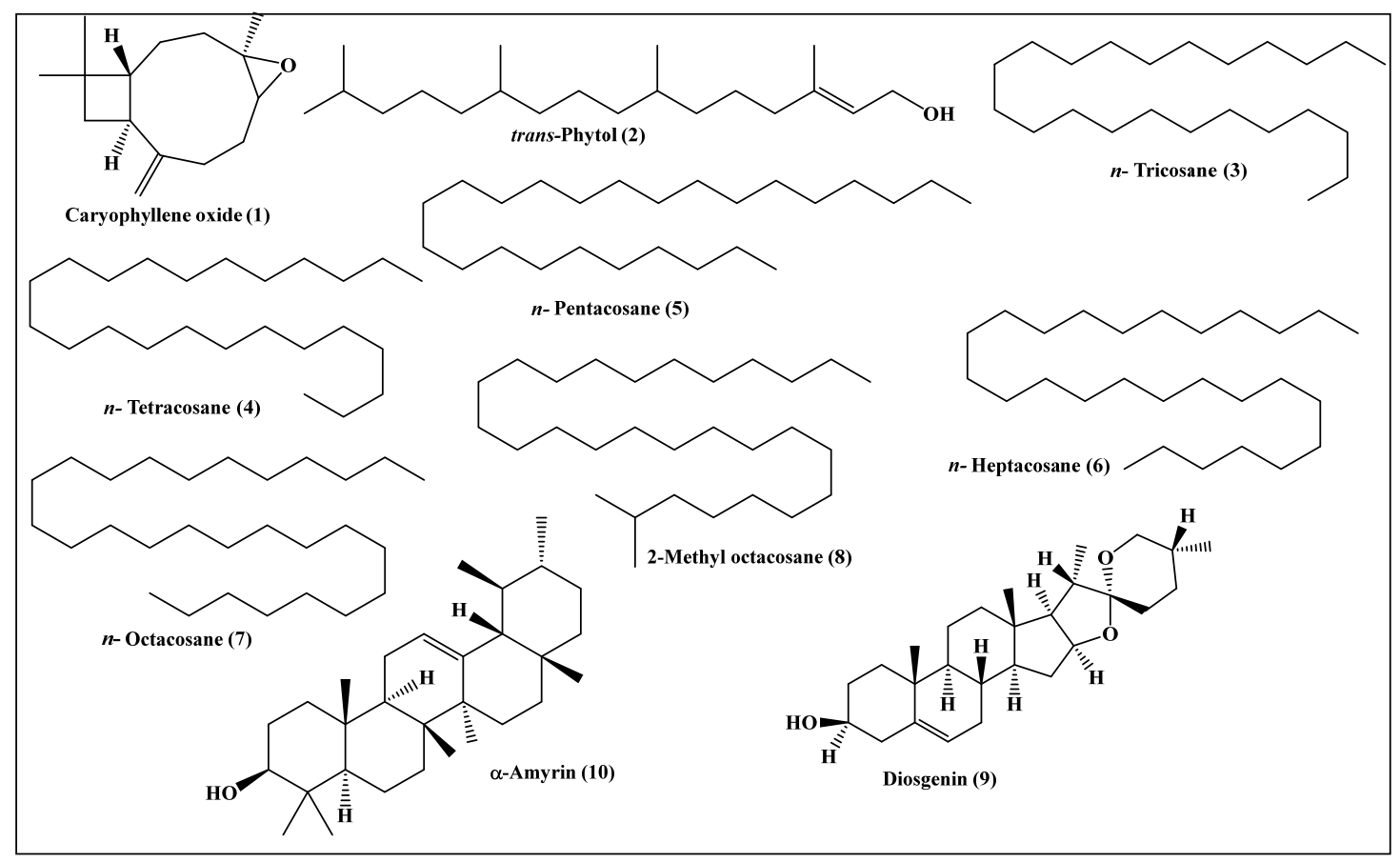

Figure 6. Scheme showing the compounds identified from the $n$-hexane fraction of $P$. odorata leaves using GC/MS analysis. 
Table 2. Compounds identified from the $n$-hexane fraction of $P$. odorata leaves using GC/MS analysis.

\begin{tabular}{|c|c|c|c|c|c|}
\hline \multirow{2}{*}{ Heading } & \multirow{2}{*}{ Compound } & \multicolumn{2}{|c|}{$\mathbf{R I}$} & \multirow{2}{*}{ Content $[\%]$} & \multirow{2}{*}{ Identification Method } \\
\hline & & Exp. & Pub. & & \\
\hline 1 & Caryophyllene oxide & 1576 & $1576[10]$ & 7.96 & MS, RI \\
\hline 2 & trans-Phytol & 2096 & $2101[11]$ & 24.06 & MS, RI \\
\hline 3 & $n$-Tricosane & 2280 & $2300[12]$ & 3.15 & MS, RI \\
\hline 4 & $n$-Tetracosane & 2404 & $2400[12]$ & 3.20 & MS, RI \\
\hline 5 & $n$-Pentacosane & 2455 & $2500[12]$ & 9.69 & MS, RI \\
\hline 6 & n-Heptacosane & 2669 & $2700[12]$ & 4.49 & MS, RI \\
\hline 7 & n-Octacosane & 2798 & $2800[12]$ & 15.28 & MS, RI \\
\hline 8 & 2-Methyl octacosane & 2854 & $2857[13]$ & 2.53 & MS, RI \\
\hline 9 & Diosgenin & 3276 & $3220[14]$ & 9.28 & MS, RI \\
\hline \multirow[t]{2}{*}{10} & $\alpha$-Amyrin & 3384 & $3382[15]$ & 13.37 & MS, RI \\
\hline & Total identified & & & 93.01 & \\
\hline
\end{tabular}

\subsection{Evaluation of the Anti-Tuberculous Activity of the Leaves n-Hexane Fraction}

$P$. odorata leaves $n$-hexane fraction revealed substantial anti-tuberculous potential versus M. tuberculosis, showing a minimum inhibition concentration (MIC) of $100 \mu \mathrm{g} / \mathrm{mL}$, whereas that of isoniazid showed MIC of $25 \mu \mathrm{g} / \mathrm{mL}$. Furthermore, P. odorata leaves $n$-hexane fraction and isoniazid inhibited $M$. tuberculosis growth by $71 \%$ and $93 \%$ at $12.5 \mu \mathrm{g} / \mathrm{mL}$, respectively. This activity is following research that previously reported the anti-tuberculous effect of $P$. odorata. A study conducted on the leaves crude methanol extract revealed poor inhibition versus $M$. tuberculosis, with MIC value of more than $128 \mu \mathrm{g} / \mathrm{mL}$; meanwhile, the inhibitory potency increased in different fractions, particularly dichloromethane fraction and its subfractions, to reach MIC values ranging between 54 to $120 \mu \mathrm{g} / \mathrm{mL}$ [16]. Additionally, MMA-ELISA (Mycobacterium tuberculosis antigen ELISA technique) revealed that the volatile oils isolated from leaves, flowers and young stems of $P$. odorata exhibited anti-TB activities in a dose estimated by $100 \mu \mathrm{L} / \mathrm{mL}$ in vitro and $300 \mu \mathrm{L} / \mathrm{mL}$ in vivo when tested separately. This activity increased significantly upon using a combination of them [17]. This was further consolidated by an additional study that showed that the TLR-4/NFKB signaling pathway is involved in the immunomodulatory effects triggered by the volatile oils isolated from $P$. odorata different organs versus TB infection in addition to their antioxidant effects [18]. Isoniazid is a pro-drug that exerts its anti-tuberculous activity after being activated in isoniazid-susceptible mycobacterial species. It significantly prohibits the formation of cell wall mycolic acids that constitutes the main component forming the envelope of M. tuberculosis. This may be attributed to its effect on certain enzymes that are involved in the synthesis of mycolic acids such as the fatty-acid enoylacyl carrier protein reductase (InhA), a complex of an acyl carrier protein (AcpM) and a $\beta$-ketoacyl-ACP synthase (KasA). Mutations have been found in the promoter regions, or less commonly, in the genes that encode these proteins in $M$. tuberculosis. These proteins decrease in strains exhibiting low resistance to isoniazid and increase in strains showing resistance to $M$. tuberculosis, suggesting that this could be an isoniazid mode of action [19].

\subsection{In Silico Molecular Modeling Study}

In silico molecular docking inhibition study of the identified compounds was performed on MTB C171Q receptor as KasA ( $\beta$-ketoacyl synthases) inhibitor (PDB ID 4C6X; $1.95 \AA$ ) that represents one of the attractive therapeutic targets to combat $M$. tuberculosis (Table 3). Root mean square deviation (RMSD) value between the co-crystallized ligand (thiolactomycin) docked within the pocket of the active center and the original molecule co-crystallized with the molecule equals 0.47 , indicating the validity of the docking process (Figure 7). Virtual screening studies revealed that trans-phytol (2) highly inhibited the 
protein with a high fitting score $(\Delta \mathrm{G}=-15.57 \mathrm{kcal} / \mathrm{mole})$ approaching that of isoniazid $(\Delta \mathrm{G}=-21.47 \mathrm{kcal} / \mathrm{mole})$ and exceeding that of thiolactomycin, the co-crystallized ligand $(\Delta \mathrm{G}=-13.03 \mathrm{kcal} / \mathrm{mole})$. This firm fitting is due to the size of the molecule in addition to the formation of three $\pi$-alkyl bonds with Phe404, Pro280, Ala215 and Van der Waals interaction with many amino acid residues existing at the active site (Figure 8).

Table 3. Free binding energies (kcal/mole) of the identified compounds in the active site of MTB C171Q receptor KasA inhibitor using in silico studies.

\begin{tabular}{|c|c|c|}
\hline Compound & $\begin{array}{l}\text { MTB C171Q Receptor KasA Inhibitor } \\
\text { (4C6X) }\end{array}$ & $\begin{array}{l}\text { Number of Formed Hydrogen and } \\
\pi \text {-Bonds with the Amino Acid Residues }\end{array}$ \\
\hline Caryophyllene oxide (1) & 8.04 & 5; Phe404, Thr313, Ile317, Ala279, Val278 \\
\hline trans-Phytol (2) & -15.57 & 3; Phe404, Pro280, Ala215 \\
\hline$n$-Tricosane (3) & FD & - \\
\hline$n$-Tetracosane $(4)$ & FD & - \\
\hline n-Pentacosane (5) & FD & - \\
\hline$n$-Heptacosane (6) & FD & - \\
\hline$n$-Octacosane $(7)$ & FD & - \\
\hline 2-Methyl octacosane (8) & FD & - \\
\hline Diosgenin (9) & 173.96 & $\begin{array}{l}\text { 6; Phe237, Met213, Pro280, Ala215, } \\
\text { Phe402, His311 }\end{array}$ \\
\hline$\alpha$-Amyrin (10) & FD & - \\
\hline Isoniazid & -21.47 & 4; Asp319, Gln322, His311, Pro280 \\
\hline Co-crystalized ligand (Thiolactomycin) & -13.03 & $\begin{array}{c}\text { 6; Gln171, His345, His311, Val278, Phe404, } \\
\text { Pro208 }\end{array}$ \\
\hline
\end{tabular}

FD: Fail to dock, “-". Means no hydrogen or $\pi$-Bonds are formed with the Amino Acid Residues; Positive values indicate unfavorable interaction.
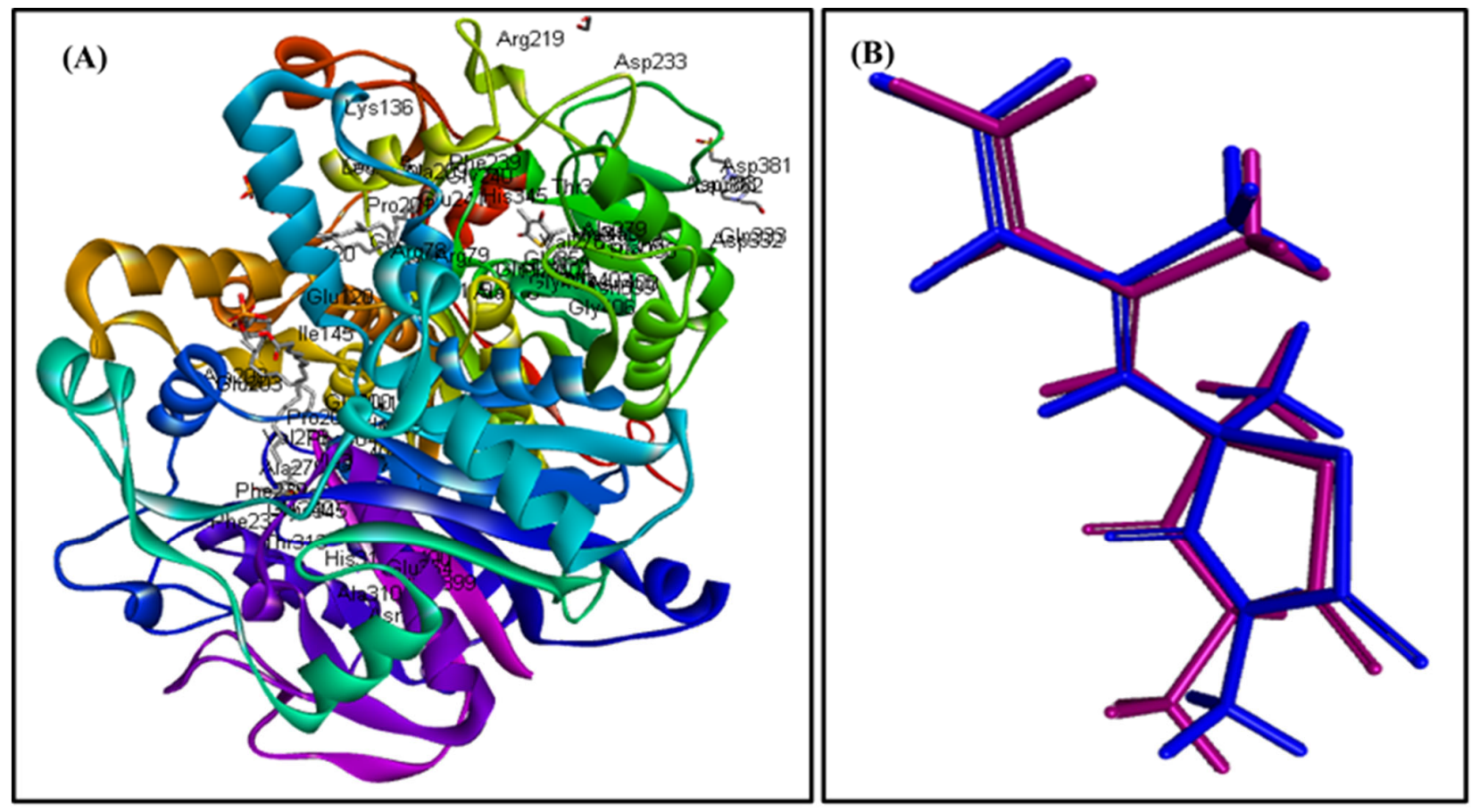

Figure 7. MTB C171Q receptor KasA inhibitor ribbon structure (A); validation of the docking experiment (B).

Many studies previously conducted on trans-phytol revealed its significant effect as an anti-tuberculous drug [20]. trans-Phytol isolated as a principal component from Leucas volkensii Gürke (Labiatae) displayed MIC value equals to $2 \mu \mathrm{g} / \mathrm{mL}$ versus $M$. tuberculosis approaching that of ethambutol, a clinically useful drug showing MIC value between 0.95 and $3.8 \mu \mathrm{g} / \mathrm{mL}$ [21]. 


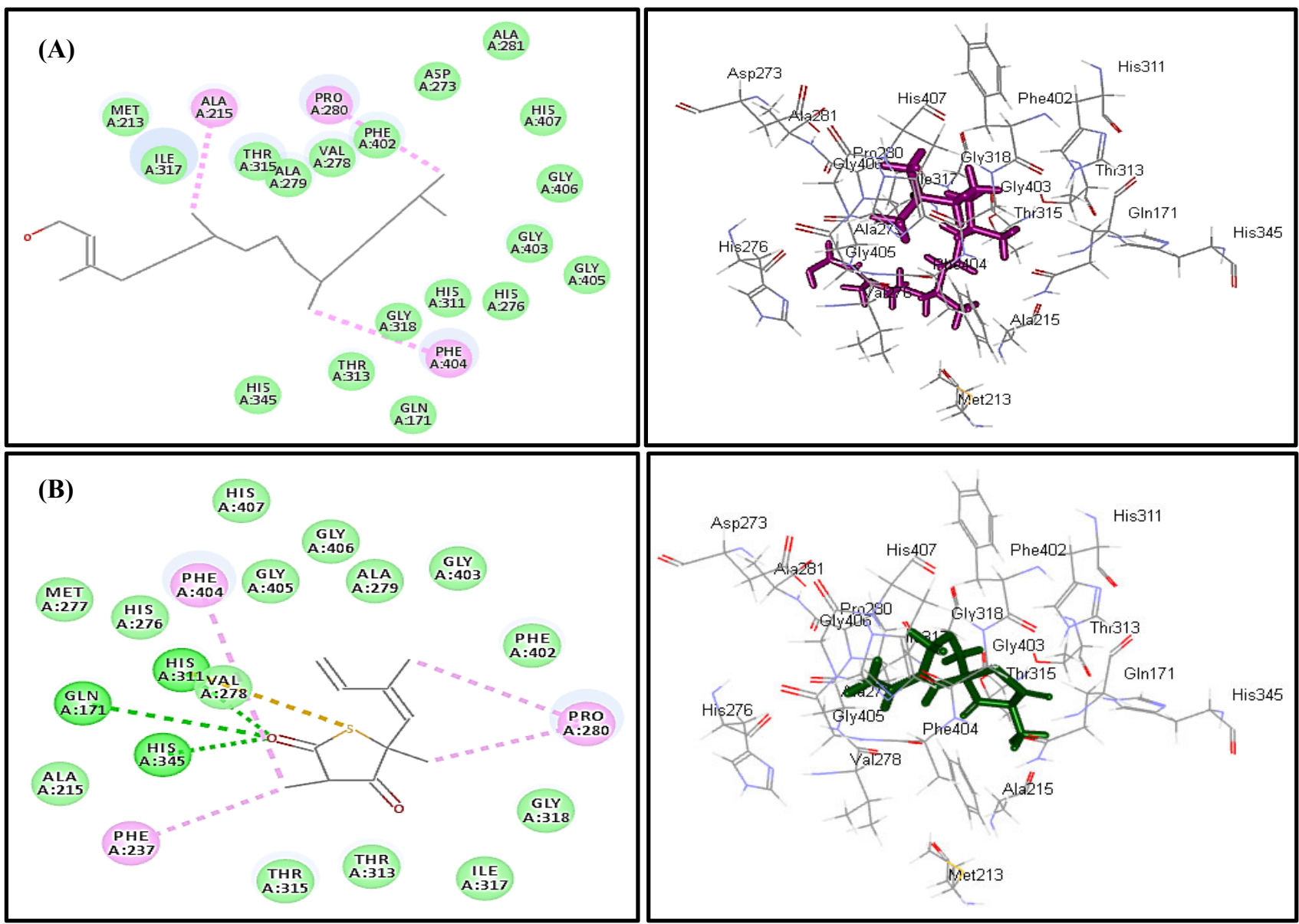

Figure 8. Two- and three-dimensional binding behavior of trans-phytol (A) and thiolactomycin; the co-crystalized ligand (B) within MTB C171Q receptor KasA inhibitor (4C6X) active site using C-docker protocol.

\subsection{ADME/TOPKAT Prediction}

The pharmacodynamic and pharmacokinetic behavior of trans-phytol, the most bioactive compound identified from the $n$-hexane fraction of $P$. odorata leaves as revealed by docking experiments, was determined. This was performed via ADME/TOPKAT prediction using Discovery Studio 4.5 (Accelrys Inc., San Diego, CA, USA) and was compared with the properties of thiolactomycin (co-crystallized ligand) and isoniazid (a standard anti-tuberculous drug) (Table 4). trans-Phytol is possibly soluble with low human intestinal absorption and unknown blood brain barrier (BBB) penetration level. Thus, it lies outside the $99 \%$ absorption ellipse, as shown in the ADMET plot (Figure 9). It shows more than $90 \%$ plasma protein binding (PBB), showing no hepatotoxicity and causes no inhibition to cytochrome P450 2D6 in contrast to isoniazid, which causes hepatotoxicity that was previously reported [22]. Additionally, trans-phytol is relatively safe being non-mutagen in chemical Ames mutagenicity test, non-carcinogen to male and female NPT (National Toxicology Program) rats with rat oral LD50 equals to $9.43 \mathrm{~g} / \mathrm{kg} \cdot \mathrm{bw}$ in contrast to isoniazid that causes mutagenicity and is carcinogen to female rats. Additionally, it does not show ocular irritancy but moderate skin irritancy. Thus, it is obvious that although trans-phytol shows lower solubility and absorption levels compared to thiolactomycin and isoniazid, it is safer, causing no mutagenic or carcinogenic effects with higher LD50 with potent therapeutic effect. Therefore, it can be subjected to certain treatments to improve its pharmacodynamic and pharmacokinetic behavior to be incorporated in pharmaceutical dosage forms to treat tuberculosis. Regarding the carcinogenicity and mutagenicity of isoniazid, this comes in accordance with what is previously published, where isoniazid and procarbazine, two 
hydrazine derivatives, were evaluated for their DNA damage that can occur in male rabbits treated with these drugs. Procarbazine displayed high carcinogenicity and mutagenicity, whereas isoniazid revealed certain carcinogenic and mutagenic effects that appear in mice. This was further confirmed in mammalian test systems [23,24].

Table 4. The absorption, distribution, metabolism, excretion, and toxicity (ADME/TOPKAT) predictions for bioactive compound identified from the $n$-hexane fraction of Premna odorata leaves, trans-phytol, thiolactomycin (co-crystallized ligand) and isoniazid.

\begin{tabular}{lccc}
\hline \multicolumn{1}{c}{ Compounds } & trans-Phytol & Thiolactomycin & Isoniazid \\
\hline ADMET parameters & & & 0 \\
Absorption Level & 3 & 0 & 4 \\
Solubility Level & 2 & 3 & 1 \\
BBB Level & 4 & 3 & False \\
PPB Level & True & True & NI \\
CPY2D6 & NI & NI & Toxic \\
Hepatotoxic & Non-toxic & Non-toxic & 67.91 \\
PSA-2D & 20.82 & 34.60 & -0.81 \\
Alog p98 & 7.3 & 2.62 & Mutagen \\
TOPKAT parameters & & & 0.48 \\
Ames prediction & Non-mutagen & Non-mutagen & Carcinogen \\
Rat oral LD50 (g/kg-bw) & 9.43 & 0.20 & Non-carcinogen \\
Rat female FDA & Non-carcinogen & Non-carcinogen & None \\
Rat Male FDA & Non-carcinogen & Carcinogen & Mild \\
Skin irritancy & Moderate & Moderate & Mild \\
Ocular irritancy & None & . & \\
\hline
\end{tabular}

$0,1,2$, and 3 indicate good, moderate, low and very low absorption, respectively; $0,1,2,3,4$, and 5 indicate extremely low, very low but possible, low, good, optimal, and too soluble, respectively; $0,1,2,3$, and 4 denote very high, high, medium, low, and undefined, penetration via BBB, respectively. PBB, plasma protein binding; FALSE means less than 90\%, TRUE means more than 90\%; NI, non-inhibitor.

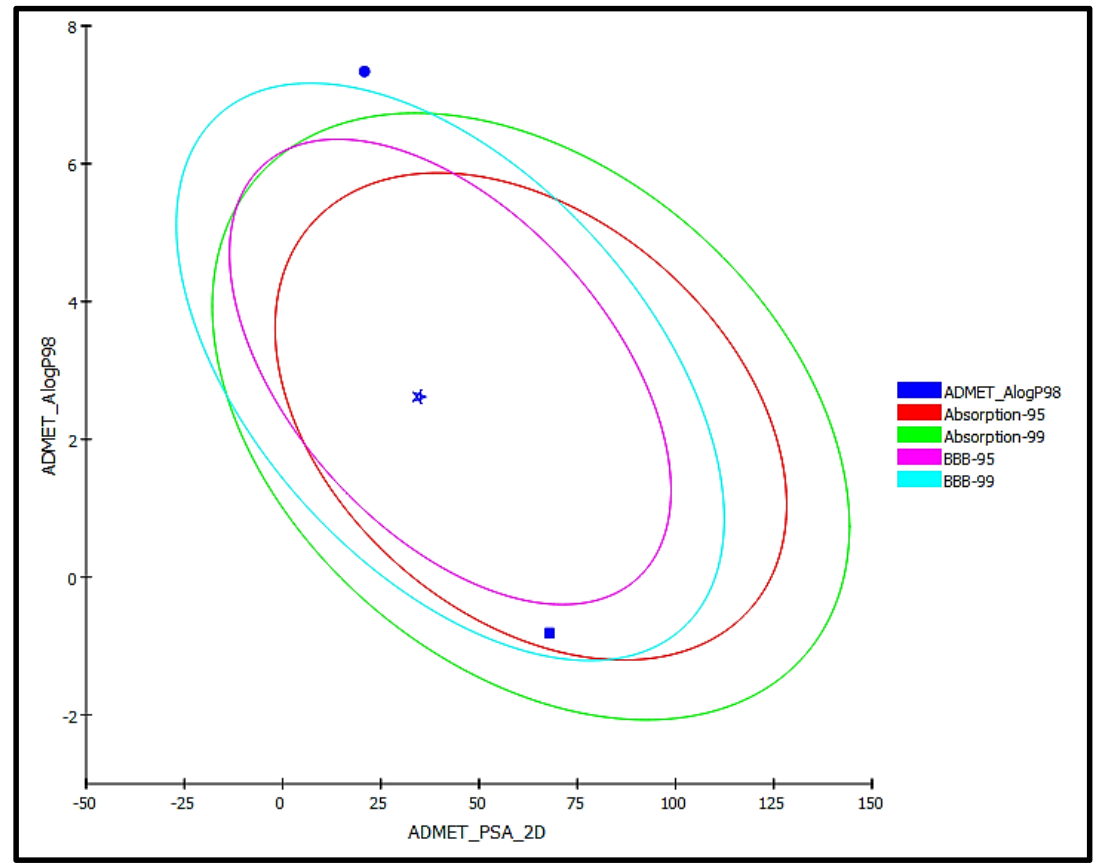

Figure 9. ADMET Plot for bioactive compound identified in $n$-hexane fraction of $P$. odorata leaves showing the $95 \%$ and $99 \%$ confidence limit ellipses corresponding to the blood-brain barrier (BBB) and the human intestinal absorption models; trans-phytol (filled circle); Co-crystalized ligand (Thiolactomycin) (star); and isoniazid (filled square) in ADMET_AlogP98. 


\section{Materials and Methods}

\subsection{Plant Material}

Stems and leaves of P. odorata Blanco (Lamiaceae) were provided from the zoo botanical garden, Giza, Egypt in May 2018. The geographical coordinates of the collection site are $30^{\circ} 1^{\prime} 28.32^{\prime \prime} \mathrm{N} ; 31^{\circ} 12^{\prime} 50.03^{\prime \prime} \mathrm{E}$, at $23 \mathrm{~m}$ altitude. Authentication was performed morphologically by taxonomy specialist Engineer Therease Labib, Consultant of Plant Taxonomy at the Ministry of Agriculture and Director of Orman Botanical Garden, Giza, Egypt. This was performed via comparing the morphological characters that can be detected by the naked eye or via using lens with low magnification power with the descriptions of the botanical drug listed in monographs or floras. These characters commonly used in morphological authentication include shape, color, and size of the leaf or fragments of it as well as fruits and flowers. Voucher specimens from P. odorata leaves and stems are maintained at the Pharmacognosy Department, Faculty of Pharmacy, Ain Shams University (PHG-P-PO-501).

\subsection{Morphological and Anatomical Investigations of the Leaves, Petioles and Stems}

Morphological studies were performed on air-dried specimens, employing the standard herbarium techniques. A canon camera (Canon PowerShot A580) was used to capture photographs of the entire plant organs. For anatomical investigations, the fresh plant samples were fixed in $70 \%$ ethanol containing $5 \%$ glycerin directly after being collected. A manual microtome (American Optical Company, model 900) was used to perform the histological sections, which were subsequently stained with malachite green and safranin. The cross-sections of the leaves, petioles, young and old stems, and the dried powdered samples were used to perform the botanical studies. Leica ICC50 HD camera integrated microscope (Carl Zeiss, Jena, German) was used to capture the photographs $[25,26]$.

\subsection{Preparation of the Leaves $n$-Hexane Fraction}

In total, $100 \mathrm{~g}$ of air-dried P. odorata Blanco (Lamiaceae) leaves were ground into a fine powder and exposed to exhaustive maceration in neat methanol $(3 \times 1 \mathrm{~L})$ and subsequently filtrated at $45^{\circ} \mathrm{C}$ in vacuo using Rotavap (Buchi Rotavapor R-114 coupled with Buchi Vac V-500 pump, Switzerland) until completely dried and then lyophilized to give $9.8 \mathrm{~g}$ of total methanol extract. An amount of $9 \mathrm{~g}$ of the lyophilized powder was solubilized in $70 \%$ methanol and subsequently fractionated using $3 \mathrm{~L}$ of distilled $n$-hexane to give $0.5 \mathrm{~g}$ of $n$-hexane fraction [27].

\subsection{Metabolic Profiling of the Leaves n-Hexane Fraction Using GC/MS Analysis}

Gas chromatography coupled with mass spectrometry (GC/MS) analyses were performed on Shimadzu GCMS-QP 2010 (Shimadzu Corporation, Koyoto, Japan) provided by Rtx-5MS $(30 \mathrm{~m} \times 0.25 \mathrm{~mm}$ i.d. $\times 0.25 \mu \mathrm{m}$ film thickness) capillary column (Restek, PA, USA) and attached to a Shimadzu mass spectrometer. The column temperature was initially set at $50^{\circ} \mathrm{C}$ for $3 \mathrm{~min}$. Then, the temperature was gradually increased from 50 to $300{ }^{\circ} \mathrm{C}$ at a rate of $5{ }^{\circ} \mathrm{C} / \mathrm{min}$ and then isothermally maintained at $300{ }^{\circ} \mathrm{C}$ for $10 \mathrm{~min}$. The temperature of the injector was kept at $280{ }^{\circ} \mathrm{C}$. Helium was used as a carrier gas at a flow rate of $1.37 \mathrm{~mL} / \mathrm{min}$. Temperatures of 280 and $220{ }^{\circ} \mathrm{C}$ were the ion source and the interface, respectively. Injection of $1 \mu \mathrm{L}$ of $1 \% v / v$ of diluted sample was achieved via a split mode adopting a split ratio of 15:1. Recording the mass spectrum was performed in EI mode of $70 \mathrm{eV}$ from $\mathrm{m} / \mathrm{z} 35$ to 500 . Compound quantitation was performed based on the normalization method, employing the reading of three chromatographic runs. Meanwhile, compound identification was made based upon the retention indices of the identified compounds with respect to a homologous series of $n$-alkanes (C8-C28) that are injected using the same conditions and by comparing mass spectra of the identified compounds with those reported in the National Institute of Standards and Technology (NIST) and Wiley library database in addition to the literature [28-30]. 


\subsection{Evaluation of the Anti-Tuberculous Activity of the Leaves n-Hexane Fraction}

The anti-tuberculous activity of $P$. odorata leaves $n$-hexane fraction was determined in vitro by microplate Alamar blue assay (MABA) using M. tuberculosis strain (RCMB 010126) obtained from the Regional Center for Mycology and Biotechnology, Cairo, Egypt, and adopting the method described by Gamal El-Din et al. (2018) Isoniazid was obtained from (Sigma Aldrich) as a standard anti-tuberculous drug. All the measurements were performed in triplicate at three independent times, and data were expressed as the mean \pm SD [31,32].

The inhibition percent was calculated from the following equation:

1 -(mean of test well/mean of B wells) $\times 100$,

MIC: the minimum concentration of drug that prohibited color change.

\subsection{In Silico Molecular Modeling Study}

In silico molecular docking study of the identified compounds was performed on one of MTB C171Q receptors such as KasA inhibitor (PDB ID 4C6X; $1.95 \AA$ A), a crucial enzyme for mycobacterial survival downloaded from the protein data bank. This was performed employing Discovery Studio 4.5 software (Accelrys Inc., San Diego, CA, USA) by adopting C-Docker protocol as previously described [33-35]. To validate the docking process, the co-crystallized ligand (thiolactomycin) was docked within the pocket of the active center and compared with the original molecule co-crystallized with the molecule. The value of RMSD (root mean square deviation) indicated the validity of the process [32].

\subsection{ADME/TOPKAT Prediction}

ADME/TOPKAT (absorption, distribution, metabolism, excretion and toxicity) prediction was performed on the bioactive compound identified from the $n$-hexane fraction of P. odorata leaves, trans-phytol, in addition to thiolactomycin (co-crystallized ligand) and isoniazid. This was performed using Discovery Studio 4.5 (Accelrys Inc., San Diego, CA, USA). Human intestinal absorption, aqueous solubility, plasma protein binding prediction (PPB), blood-brain barrier penetration (BBB), hepatotoxicity level and cytochrome P450 (2D6) were chosen as ADME descriptors. Furthermore, rat oral LD50, carcinogenic affect female and male rat NPT (National Toxicology Program), skin and ocular irritation and Ames mutagenicity were chosen as toxicity parameters [36].

\section{Conclusions}

Botanical study of $P$. odorata leaf, petiole and stem showed its great resemblance to other members in Premna genus and Lamiaceae family, such as the presence of glandular peltate trichomes and diacytic stomata. P. odorata leaves $n$-hexane fraction revealed substantial anti-tuberculous potential versus M. tuberculosis. trans-Phytol constitutes the major compound in the $n$-hexane fraction of the leaves, as demonstrated by GC/MS analysis. trans-Phytol highly inhibited the MTB C171Q receptor as KasA ( $\beta$-ketoacyl synthases), approaching isoniazid and exceeding that of thiolactomycin, the co-crystallized ligand, as revealed from the docking studies. ADME/TOPKAT predictions showed that transphytol possesses less solubility and absorption levels when compared to thiolactomycin and isoniazid, tested as standard molecules. Still, it is safer, causing no mutagenic or carcinogenic effects with higher LD50. Thus, P. odorata can act as a source of lead entities to treat tuberculosis. However, further studies are recommended to be performed on other fractions of the plant, such as the polar fractions and their subsequent isolated compounds to evaluate their biological activities. In addition, it is highly recommended to directly use $n$-hexane for the extraction, and thus more non-polar compounds will be extracted and concomitantly will increase the robustness of the study.

Author Contributions: Conceptualization, methodology, software, writing-original draft preparation, F.S.Y.; writing—review and editing, E.O.; supervision, writing-review and editing; funding acquisition, N.M.A.M.; supervision, writing-review and editing, M.L.A. All authors have read and agreed to the published version of the manuscript. 
Funding: This research was funded by King Saud University Researchers Supporting Project number (RSP-2021/294), King Saud University, Riyadh, Saudi Arabia.

Institutional Review Board Statement: Not applicable.

Informed Consent Statement: Not applicable.

Data Availability Statement: Data are available upon request from the first author.

Acknowledgments: All the authors would like to thank the King Saud University Researchers Supporting Project number (RSP-2021/294), King Saud University, Riyadh, Saudi Arabia.

Conflicts of Interest: The authors declare no conflict of interest.

\section{References}

1. Munir, A.A. A taxonomic revision of the genus Premna L. (Verbenaceae) in Australia. J. Adel. Bot. Gard. 1984, 7, 1-43.

2. Harley, R.; Atkins, S.; Budanstev, A.; Cantino, P.; Conn, B.; Grayer, R.; Harley, M.; De Tok, R.; Krestovskaja, T.; Morales, R. Flowering plants, dicotyledons. Fam. Genera Vasc. Plants. 2004, 6, 167-275.

3. Dianita, R.; Jantan, I. Ethnomedicinal uses, phytochemistry and pharmacological aspects of the genus Premna: A review. Pharm. Biol. 2017, 55, 1715-1739. [CrossRef]

4. de Kok, R. The genus Premna 1. (Lamiaceae) in the Flora Malesiana area. Kew Bull. 2013, 68, 55-84. [CrossRef]

5. Altyar, A.E.; Ashour, M.L.; Youssef, F.S. Premna odorata: Seasonal metabolic variation in the essential oil composition of its leaf and verification of its anti-ageing potential via in vitro assays and molecular modelling. Biomolecules 2020, 10, 879. [CrossRef]

6. Pinzon, L.C.; Uy, M.M.; Sze, K.H.; Wang, M.; Chu, I.K. Isolation and characterization of antimicrobial, anti-inflammatory and chemopreventive flavones from Premna odorata Blanco. J. Med. Plants Res. 2011, 5, 2729-2735.

7. Abdulrahaman, A.; Oladele, F. Stomata, trichomes and epidermal cells as diagnostic features in six species of genus Ocimum L. (Lamiaceae). Nig. J. Bot. 2005, 18, 214-223.

8. Kowalski, R.; Kowalska, G.; Jankowska, M.; Nawrocka, A.; Kałwa, K.; Pankiewicz, U.; Włodarczyk-Stasiak, M. Secretory structures and essential oil composition of selected industrial species of Lamiaceae. Acta Sci. Pol. Hort.Cul. 2019, 18, 53-69. [CrossRef]

9. Babu, K.; Dharishini, M.P.; Austin, A. Anatomical and thin layer chromatographic identification of root, root-bark, and leaf of Premna serratifolia L. Int. J. Pharmacog. 2018, 5, 302-307.

10. Yusuf, M.; Begum, J.; Mondello, L.; d'Alcontres, I.S. Studies on the essential oil bearing plants of Bangladesh. Part VI. Composition of the oil of Ocimum gratissimum L. Flavour Fragr. J. 1998, 13, 163-166.

11. Pino, J.A.; Marbot, R. Volatile flavor constituents of acerola (Malpighia emarginata DC.) fruit. J. Agric. Food Chem. 2001, 49, 5880-5882. [CrossRef] [PubMed]

12. Korany, D.A.; Ayoub, I.M.; Labib, R.M.; El-Ahmady, S.H.; Singab, A.N.B. The impact of seasonal variation on the volatile profile of leaves and stems of Brownea grandiceps (Jacq.) with evaluation of their anti-mycobacterial and anti-inflammatory activities. South Afr. J. Bot. 2021, 142, 88-95. [CrossRef]

13. Steinmetz, I.; Schmolz, E.; Ruther, J. Cuticular lipids as trail pheromone in a social wasp. Proc. R. Soc. London. Ser. B Biol. Sci. 2003, 270, 385-391. [CrossRef] [PubMed]

14. Van Gelder, W.; Jonker, H.; Huizing, H.; Scheffer, J. Capillary gas chromatography of steroidal alkaloids from solanaceae: Retention indices and simultaneous flame ionization/nitrogen-specific detection. J. Chromatogr. A 1988, 442, 133-145. [CrossRef]

15. Todua, N. Retention Data. NIST Mass Spectrometry Data Center. 2011.

16. Lirio, S.B.; Macabeo, A.P.; Paragas, E.M.; Knorn, M.; Kohls, P.; Franzblau, S.G.; Wang, Y.; Aguinaldo, M.A. Antitubercular constituents from Premna odorata Blanco. J. Ethnopharmacol. 2014, 154, 471-474. [CrossRef] [PubMed]

17. Elmaidomy, A.H.; Hassan, H.M.; Amin, E.; Mohamed, W.; Hetta, M.H. Premna odorata volatile oil as a new Mycobacterium tuberculosis growth inhibitor for the control of tuberculosis disease. Eur. J. Med. Plants 2017, 21, 1-11. [CrossRef]

18. Waleed, A.M.; Samah, S.A.; Mona, F.S.; Abeer, H.E.; Hossam, M.H.; Elham, A.; Mona, H.H. Immunomodulatory effect of Premna odorata volatile oils in Mycobacterium tuberculosis by inhibiting TLR4/NF-кB pathway. J. Herb. Pharmacol. 2019, 8, 1-7.

19. Somoskovi, A.; Parsons, L.M.; Salfinger, M. The molecular basis of resistance to isoniazid, rifampin, and pyrazinamide in Mycobacterium tuberculosis. Res. Res. 2001, 2, 1-5.

20. Saludes, J.P.; Garson, M.J.; Franzblau, S.G.; Aguinaldo, A.M. Antitubercular constituents from the hexane fraction of Morinda citrifolia Linn. (Rubiaceae). Phytother. Res. 2002, 16, 683-685. [CrossRef]

21. Rajab, M.S.; Cantrell, C.L.; Franzblau, S.G.; Fischer, N.H. Antimycobacterial activity of (E)-phytol and derivatives: A preliminary structure-activity study. Planta Med. 1998, 64, 2-4. [CrossRef]

22. Wang, P.; Pradhan, K.; Zhong, X.-b.; Ma, X. Isoniazid metabolism and hepatotoxicity. Acta Pharm. Sinica B 2016, 6, 384-392. [CrossRef]

23. Bürgin, H.; Schmid, B.; Zbinden, G. Assessment of DNA damage in germ cells of male rabbits treated with isoniazid and procarbazine. Toxicology 1979, 12, 251-257. [CrossRef] 
24. Röhrborn, G.; Propping, P.; Buselmaier, W. Mutagenic activity of isoniazid and hydrazine in mammalian test systems. Mutat. Res.Fund. Mol. Mech. Mut. 1972, 16, 189-194. [CrossRef]

25. Milad, R.; Youssef, F.S.; Ashour, M.L.; Singab, A.N. Botanical and genetic characteristics of Eremophila maculata and Eremophila purpurascens (Scrophulariaceae). World J. Pharm. Res. 2013, 2, 2711-2736.

26. Youssef, F.S.; Ashour, M.L.; Wink, M. Morphological, anatomical, genetical and high performance thin layer chromatography profiling of Buddleia indica (Scrophulariaceae). Flora 2018, 246, 83-95. [CrossRef]

27. Thabet, A.A.; Youssef, F.S.; Korinek, M.; Chang, F.-R.; Wu, Y.-C.; Chen, B.-H.; El-Shazly, M.; Singab, A.N.B.; Hwang, T.-L. Study of the anti-allergic and anti-inflammatory activity of Brachychiton rupestris and Brachychiton discolor leaves (Malvaceae) using in vitro models. BMC Complement. Alt. Med. 2018, 18, 299. [CrossRef] [PubMed]

28. Ayoub, I.M.; Youssef, F.S.; El-Shazly, M.; Ashour, M.L.; Singab, A.N.B.; Wink, M. Volatile constituents of Dietes bicolor (Iridaceae) and their antimicrobial activity. Z. Naturforsch. C 2015, 70, 217-225. [CrossRef] [PubMed]

29. Youssef, F.S.; Hamoud, R.; Ashour, M.L.; Singab, A.N.; Wink, M. Volatile oils from the aerial parts of Eremophila maculata and their antimicrobial activity. Chem. Biodivers. 2014, 11, 831-841. [CrossRef] [PubMed]

30. Mamadalieva, N.Z.; Youssef, F.S.; Ashour, M.L.; Sasmakov, S.A.; Tiezzi, A.; Azimova, S.S. Chemical composition, antimicrobial and antioxidant activities of the essential oils of three Uzbek Lamiaceae species. Nat. Prod. Res. 2019, 33, 2394-2397. [CrossRef] [PubMed]

31. Gamal El-Din, M.I.; Youssef, F.S.; Ashour, M.L.; Eldahshan, O.A.; Singab, A.N.B. Comparative Analysis of Volatile constituents of Pachira aquatica Aubl. and Pachira glabra Pasq., their anti-mycobacterial and anti-helicobacter pylori activities and their metabolic discrimination using chemometrics. J. Ess. Oil Bear. Plants 2018, 21, 1550-1567. [CrossRef]

32. Youssef, F.S.; Altyar, A.E.; Omar, A.M.; Ashour, M.L. Phytoconstituents, in vitro anti-infective activity of Buddleja indica Lam., and in silico evaluation of its SARS-CoV-2 inhibitory potential. Front. Pharmacol. 2021, 12, 298. [CrossRef] [PubMed]

33. Thabet, A.A.; Youssef, F.S.; El-Shazly, M.; El-Beshbishy, H.A.; Singab, A.N.B. Validation of the antihyperglycaemic and hepatoprotective activity of the flavonoid rich fraction of Brachychiton rupestris using in vivo experimental models and molecular modelling. Food Chem. Toxicol. 2018, 114, 302-310. [CrossRef] [PubMed]

34. Talaat, A.N.; Ebada, S.S.; Labib, R.M.; Esmat, A.; Youssef, F.S.; Singab, A.N.B. Verification of the anti-inflammatory activity of the polyphenolic-rich fraction of Araucaria bidwillii Hook. using phytohaemagglutinin-stimulated human peripheral blood mononuclear cells and virtual screening. J. Ethnopharmacol. 2018, 226, 44-47. [CrossRef]

35. Labib, R.; Youssef, F.; Ashour, M.; Abdel-Daim, M.; Ross, S. Chemical composition of Pinus roxburghii bark volatile oil and validation of its anti-inflammatory activity using molecular modelling and bleomycin-induced inflammation in Albino mice. Molecules 2017, 22, 1384. [CrossRef]

36. Mollica, A.; Zengin, G.; Durdagi, S.; Ekhteiari Salmas, R.; Macedonio, G.; Stefanucci, A.; Dimmito, M.P.; Novellino, E. Combinatorial peptide library screening for discovery of diverse $\alpha$-glucosidase inhibitors using molecular dynamics simulations and binary QSAR models. J. Biomol. Str. Dyn. 2019, 37, 726-740. [CrossRef] 